\title{
Sustainability of the Development of Sharia Economic Law in Indonesia: A Social History Approach
}

\author{
Illy Yanti \\ Faculty of Sharia \\ UIN Sultan Thaha Saifuddin Jambi \\ Jambi, Indonesia \\ illy.yanti@yahoo.com
}

\author{
Addirrahman \\ Faculty of Islamic Economic and Business \\ UIN Sultan Thaha Saifuddin Jambi \\ Jambi, Indonesia \\ addiarrahman@uinjambi.ac.id
}

\begin{abstract}
Positivization becomes the dominant approach in the development of sharia economic law in Indonesia. In fact, in the perspective of social history, Islamic law in the economic and business fields has become a law that lives in the middle of society or customary law. This article aims to look at the dynamics of Islamic economic law in customary law that lives in the community. The transformation of Islamic economic law into customary law can sustain Islamic economic and business development through a cultural approach. This also shows the importance of a cultural perspective in the development of Islamic economic law, in addition to the positivization approach.
\end{abstract}

Keywords: Sharia Economic Law, Sustainability, Indonesia, Social History Approach

\section{INTRODUCTION}

The mixed legal system (civil law and Islamic law), as it applies in Indonesia, according to Grassa \& Gazdar, impedes the growth rate of Islamic economics. This is different from countries that adopt a system common law or a mix of common law and Islamic law, such as in Malaysia, which is more flexible so that its growth is faster (Grassa \& Gazdar, 2014). This finding needs to be reviewed, for example by looking at the legal structure, legal substance, and legal culture. from a legal system. In other words, as Friedman emphasized, a law can be effective if it is supported by these three elements (Friedman, 1998).

Sharia economic law in Indonesia has developed quite rapidly, both in terms of legal structure and legal substance. In terms of legal structure, the competence of sharia economic dispute resolution has been fully delegated to the Religious Courts, as mandated by Law No. 3 of 2006 . Whereas, judging from the legal substance, it has been included in sharia banking laws, zakat, waqf, and other regulations that govern technically the implementation of sharia economics, particularly those relating to financial institutions. Legalization of Supreme Court Regulation (PERMA) No. 2 of 2008 concerning Sharia economic guidelines in the form of Compilation of Sharia Economic Law (KHES) helped strengthen the substance of sharia economic law. Therefore there is no doubt that in substance, the implementation of Islamic economic cases in the midst of the community can certainly be run well if they follow the established guidelines.

At the level of practice, the implementation of Islamic economic law is quite good, although it has not shown a large expansion. Islamic banking market share has not exceeded
$5 \%$. On the other hand, the resolution of Islamic economic disputes through religious courts is also still small. The lack of Islamic economic cases submitted to the religious court, which is only about 5 cases, according to Direktorat Pranata dan Tata Laksana Perkara Perdata Agama, five cases out of 363,041 handled by religious courts in Indonesia. The five cases are spread in Central Java two cases and the rest in Yogyakarta. Islamic economic matters that occur are usually settled outside the court (Manan, 2017). However, the latest information obtained, although not a lot of Islamic economic cases, the submission of Islamic economic dispute cases in the religious court environment to date is almost evenly distributed, especially in Java (Irfan, $\mathrm{tt}$ ). This empirical fact has an impact on the development of Islamic economic law through the judiciary has stagnated. Disputing parties, especially from financial institutions, prefer dispute resolution through peaceful efforts with the intention of protecting the good name of the company.

The long process of sharia economic law formation has made it part of the law that lives in the community (living law) or integrates with customary law. However, the secularization carried out by the Dutch colonials slowly affected the legal awareness of the community, so that in certain regions, Islamic law was considered a separate part of adat law (Latif, 2007). Secularization also impacted the colonial psychology of some Muslim communities who did not accept Dutch law, and encouraged the application of Islamic law (Effendi, 2009). Political tensions continued, but at the same time the existence of customary law was increasingly marginalized.

\section{THE RELATION OF CUSTOMARY LAW AND ISLAMIC LAW}

In theory, the relation of customary law and Islamic law in Indonesia can be explained through the theory of receptio in complexu, receptie, receptie a contrario, receptie exit. It was Lodewijk Willem Christian van den Berg (1845-1927) who first coined the theory of receptio in complexu. According to him, the law follows a person's religion, if he is a Muslim then what applies to him is Islamic law. This theory was basically quite beneficial to the existence of Islamic law, so that the Dutch government recognized Islamic law as applied by the Indonesian people at that time. However, this theory was later refuted by Christian Snouck Hurgronje (1857-1936), a Dutch adviser who had studied Islamic teachings in Mecca a lot. Based on his investigation of the people of Aceh and Gayo, the law that applies to these communities is not Islamic law, but customary law. Islamic law has indeed influenced 
customary law, but this influence has legal force if it has been truly accepted by customary law. This theory was then followed by many scholars, especially by Cornelis van Vollenhoven and Bertrand ter Haar (Daud Ali, 1993).

The theory put forward by Hurgronje gave birth to the law of secularization in Indonesia. As explained earlier, this strategy greatly influenced the development of Islamic law in the colonial period, especially after independence. Of course, this theory, after Indonesia's independence received strong criticism from Indonesian scholars. According to Hazairin (1905-1975), the theory developed by his teacher, ter Haar, was an attempt by the Dutch to hinder the progress of Islam in Indonesia. Receptionist theory who seeks to lead Muslims not to obey and carry out Islamic teachings. Furthermore, Sayuti Thalib asserted that the importance of the family from the perspective of reception theory. According to him, precisely customary law can be accepted as law if it is in line with Islamic law. This theory came to be known as the theory receptie exit.

\section{SHARIA ECONOMIC LAW AS A LIVING LAW}

Apart from these theories, we can trace parts of Islamic economic law that have become living law in the community. In the Acehnese society, the belief is that "Adat bak Poteumeureuhom, hukom bak Sjiah Kuala", Hukom ngon adat lagee zat ngon sipheuet." This means that the lives and livelihoods of Acehnese people are based on adat (led by Sulthan) and law (led by Sulthan). Ulema: while law and custom are inseparable, such as substance and nature, the Acehnese people consider that adat has been formed and regulated in such a way by the kings of Aceh since ancient times, especially after the establishment of the Kingdom of Aceh Darussalam under the leadership of Sultan Ali Mugayatsyah who ruled in AD 1511-1530 (Moehammed Hoessein, 1970)

As codified by Hoessein, Acehnese custom governs every aspect of community life, such as marital and divorce issues, pregnancy, parental obligations, beliefs about illness, misfortune, distribution of inheritance, maintenance of property others, maintaining, and working on other people's gardens or land, 'ubudiyah, and other matters in bid social, economic, criminal, etc. (Hoessein, 1970).

Since the 16th century, the people of Aceh have known cooperation agreements called mawah (Yunus, 2015). Simply put, the practice of mawah is the same contract mudharabah as theas regulated in the book of fiqh. Namely, the agreement between the owners of capital (shahibul maal) and the manager (mudharib), while the results are divided based on the ratio agreed upon. In the study of Islamic economics, mudaraba is a key instrument in eradicating ribawi practices (Abdul-Rahman, Abdul Latif, Muda, \& Abdullah, 2014). Until now, the practice of mawah remains popular in Acehnese society. It is applied in various fields, such as agriculture, plantation, animal husbandry and others (Ibrahim, 2012).

The existence of mawah for generations has benefited the people of Aceh. He became a powerful instrument in dealing with the economic crisis, poverty alleviation, reducing unemployment in the village, and others. In Kuta Baro District, for example, practices mawah were developed into poverty alleviation strategies (Nelly \& Rahmi, 2017). Not only that, moral values which become the principle of the practice of mawah are proof that the process of acculturation and Islamization of Islamic teachings has become a living law in the community. How not, mawah carried out based on verbal agreements on the basis of trust and honesty. This practice has been carried out down and down, and if there is a dispute, the settlement is carried out by the Customary Court under the Aceh Customary Institution, as stipulated in Aceh Qanun No. 9 of 2008 concerning the Development of Customary Life and Customs (Fitria Mardhatillah, 2017).

The Acehnese custom also stressed that it is not permissible to take usury in the loan agreement. However, in the case of a gala or pawn agreement, the people of Aceh remain trapped in the practice of riba or usury. This is because the pawn holder (gala) holds and takes the proceeds from the item. This practice, in the jurisprudence, by jumhur ulama is prohibited, except from the Hanbali school. agreement gala This seems to be similar to the contract of pawnshop in the Minangkabau community. In general, the implementation of gala is carried out by people who are experiencing economic difficulties. Iskandar and Addiarrahman's study emphasized the existence of irregularities in the practice of pawning in customary law from sharia provisions, caused by the evil practices carried out by middlemen, especially from the Chinese who received licentie stelsel from the Dutch government in colonial times (Iskandar \& Addiarrahman, 2018). These practices, then, influence community groups, especially those from the rich, doing the same thing.

\section{INSTITUTIONALIZATION OF LOCAL WISDOM AS A BASE FOR SUSTAINABLE SHARIA ECONOMIC DEVELOPMENT}

The inclusion of sharia economic legal principles into the customary legal system related to economic activities, confirms that local wisdom can be used as a basis for the economic development of the people. Many models can be developed, such as (1) accommodative models; (2) institutional; (3) creative economy; and (4) networking (Addiarrahman, 2013b).

Accommodation of local wisdom is implemented by adopting economic systems that have become entrenched in people's lives. The practices Mawah can basically be accommodated by Islamic financial institutions as a product variant to serve the needs of the community. This is at the same time responding to the uncertainty of sharia banking applying the mudharah agreement as an instrument for channelling funds. As is known, so far the contract murabaha dominates banking practices so that it becomes a critical gap to commitments in implementing sharia principles (Saeed, 1999a, 1999b; Syaparuddin, 2014).

The institutional model can be developed by making social institutions an important part of community life as a model for the economic development of the people. Social institutions such as the surau in the Minangkabau community, once had a central role in regulating the economic life of the community. Therefore, this can be exploited by revitalizing the function of the mosque, so as confirmed by Sidi Gazalba, the mosque or mosque can become a center of worship as well as Islamic culture (Sidi Gazalba, 1962). This also anticipates that in the mosques will not found the idle fund, while the surrounding community experiences economic difficulties (Adnan, 2013). 
The creative economy is now an important part of increasing economic productivity. The availability of technology encourages a lot of creativity, so as to produce products that meet the needs of the community, especially for millennial generations. At this point, local wisdom can be an inspiration. As seen in the development of architecture, music, and so forth.

Furthermore, strong social relations within an indigenous community can form a strong economic network. In the Minangkabau community, the tradition of wandering precisely becomes a strength of the diaspora which is very beneficial for the Minangkabau community, both in the overseas and in the realm of Minang itself. For example, the existence of the Sulit Air Sepakat (SAS) monitoring organization has greatly contributed to various development activities in Nagari Sulit Air, Solok (Addiarrahman, 2013a).

\section{CONCLUSION}

This article concludes that Islamic economic law has become part of the law that lives in the community or living law. This condition has indirectly shaped the legal culture of Indonesian society. Therefore, the sustainability of Islamic economic development requires a cultural approach in addition to a positivation approach.

\section{ACKNOWLEDGMENT}

This article is part of the results of research on "The Role of the Legal Culture in the Development of Sharia Economic Laws in Indonesia" funded by DIPA UIN Sultan Thaha Saifuddin Jambi in 2018. The researchers thanked the assistance, so that this research could be completed.

\section{REFERENCES}

[1] Abdul-Rahman, A., Abdul Latif, R., Muda, R., \& Abdullah, M. A. (2014). Failure and potential of profitloss sharing contracts: A perspective of New Institutional, Economic (NIE) Theory. Pacific-Basin Finance Journal, 28 https://doi.org/10.1016/j.pacfin.2014.01.004

136-151.

[2] Addiarrahman. (2013a). Baragiah Ka Kampuang: Spirit Filantropis Perantau Sulit Air. Turast: Jurnal Penelitian dan Pengabdian, 1(1), 67-80.

[3] Addiarrahman. (2013b). Mengindonesiakan ekonomi Islam: Formulasi kearifan lokal untuk pengembangan ekonomi umat. Yogyakarta: Penerbit Ombak.

[4] Adnan, M. A. (2013). An investigation of the financial management practices of the Mosques in the Special Region of Yogyakarta Province, Indonesia. Proceeding of Sharia Economics Conference-Hannover, 9.
[5] Effendi, B. (2009). Islam dan negara: Transformasi gagasan dan praktik politik Islam di Indonesia. Paramadina.

[6] Fitria Mardhatillah. (2017). Analisis terhadap Penyelesaian Sengketa Mawah di Lembaga Adat Aceh. UIN Sunan Kalijaga, Yogyakarta.

[7] Grassa, R., \& Gazdar, K. (2014). Law and Islamic Finance: How Legal Origins Affect Islamic Finance Development? Borsa Istanbul Review, 14(3), 158-166. https://doi.org/10.1016/j.bir.2014.05.001

[8] Ibrahim, A. (2012). Praktik Ekonomi Masyarakat Aceh Dalam Konteks Ekonomi Islam: Kajian Terhadap Sistem Mawah Dan Gala. Proceeding of the Aceh Development International Conference, IIUM.

[9] Irfan, A. (t.t.). Dinamika Penyelesaian Sengketa Perbankan Syariah Di Lingkungan Peradilan Agama Dari Masa Ke Masa. Retrieved from https://www.academia.edu/27253456/DINAMIKA_PE NYELESAIAN SENGKETA PERBANKAN SYARI AH_DI_LINGKUNGAN_PERADILAN_AGAMA_DA RI_MASA_KE_MASA

[10] Iskandar, I., \& Addiarrahman, A. (2018). Sejarah Sosial Perkembangan Hukum Gadai dan Rahn (Gadai Syariah) di Indonesia. Al-Risalah, 17(02). Diambil dari http://ejournal.lp2m.uinjambi.ac.id/ojp/index.php/alrisalah/article/view/62

[11] Latif, Y. (2007). Dialektika Islam: Tafsir sosiologis atas sekularisasi dan islamisasi di Indonesia. Jalasutra.

[12] Lawrence Meier Friedman, American Law : an Intriduction, Second edition, (New York : W.W. Norton \& Company, 1998),

[13] Manan, H. A. (2017). Hukum Ekonomi Syariah: Dalam Perspektif Kewenangan Peradilan Agama. Prenada Media.

[14] Nelly, N., \& Rahmi, R. (2017). Strategi Pengentasan Kemiskinan Berbasis Kearifan Lokal Masyarakat Aceh Melalui Praktek Adat Mawah (Bagi Hasil Usaha) Di Kecamatan Kuta Baro. Prosiding Seminar Nasional USM, 1.

[15] Saeed, A. (1999a). Indonesian Islamic Banking in Historical and Legal Context. Dalam Tim Lindsey (Ed.), Indonesia: Law and Society. Sydney: Federation Press.

[16] Saeed, A. (1999b). Islamic Banking Moving Towards a Pragmatic Approach? ISIM Newsletter, 3, 1.

[17] Syaparuddin, S. (2014). Kritik Abdullah Saeed terhadap Praktik Pembiayaan Murabahah pada Bank Islam. ISLAMICA: Jurnal Studi Keislaman, 6(2), 375-388. https://doi.org/10.15642/islamica.2012.6.2.375-388

[18] Yunus, F. (2015, Oktober 21). Initiating A Traditional and Community-Based Islamic Economic and Finance Model: Case Study of Beng Mawah an Aceh, Indonesia Co-operative. Presented at International Congress on Islamic Economic and Business, Turkey. 